\title{
Analyzing and Estimating Portfolio Performance of Bangladesh Stock Market
}

\author{
${ }^{1}$ Md. Zobaer Hasan, ${ }^{1}$ Anton Abdulbasah Kamil, ${ }^{2}$ Adli Mustafa and ${ }^{3}$ Md. Azizul Baten \\ ${ }^{1}$ Department of Mathematics, School of Distance Education, \\ ${ }^{2}$ Department of Mathematics, School of Mathematical Sciences, \\ Universiti Sains Malaysia, Penang, Malaysia \\ ${ }^{3}$ Department of Decision Science, School of Quantitative Sciences, \\ Universiti Utara Malaysia, Darul Aman, Malaysia
}

Received 2012-08-17, Revised 2012-12-19; Accepted 2013-03-18

\begin{abstract}
Capital Asset Pricing Model (CAPM) is one of the most important developments in the finance literature. Simply, CAPM is a model that describes the relationship between risk and expected return. The theoretical validity of CAPM is well tested and accepted but the practical validity of CAPM is in questioned. This study is designed to analyze and estimate the portfolio performance of Bangladesh stock market in a CAPM framework. For this study, monthly stock returns from 80 companies for the period of January 2005 to December 2009 are chosen. In order to examine whether the CAPM is satisfied in the portfolio or not, the 80 stocks are arranged in descending order of beta and 10 portfolios are being made of eight stocks in each. The All Share Price Index (DSI) is used as a proxy for the market portfolio and Bangladesh government 3-Month T-bill rate is used as the proxy for the risk-free asset. The results of this analysis show that the intercept terms are not significantly different from zero, linearity in the securities market line and insignificant unique risk for the 10 portfolios during the period. But, the results in term of slope contradict the CAPM hypothesis and indicate evidence against the CAPM in the portfolios. This analysis will obviously be used as a basis of reference for future investigates and the researchers and they will get proper instruction from this study.
\end{abstract}

Keywords: Stock Returns, Portfolio Returns, Asset Pricing Models, Bangladesh Stock Market, NonFinancial Companies, Standard Deviation, Systematic Risk, Unique Risk

\section{INTRODUCTION}

The stock markets (either developed or emerging) play very crucial roles for the economy of a country. The emerging stock markets are contributing towards the economy by the way of Gross Domestic Product (GDP) growth, investment attraction and expansion and developing a market place for potential investors. The practice of well tested pricing model like Capital Asset Pricing Model (CAPM) in the emerging stock market is very rare. It is due to the absence of proper validity test of this model. A sound and well tested and accepted pricing model can contribute more to emerging markets for their sound operation. The investors, management, policy makers, investment companies, consultants, regulators of the emerging markets can be guided by a sound pricing model.

Markowitz (1952) and Tobin (1958) were the researchers for the development of asset pricing models. Early theories suggested that the risk of an individual security is the standard deviation of its returns. Sharpe (1964); Lintner (1965) and Mossin (1968) had independently developed a computationally efficient and standard method called CAPM which predicts that the expected return on an asset is linearly related to systematic risk. In the early stage, some financial

Corresponding Author: Md. Zobaer Hasan, Department of Mathematics Section, School of Distance Education, Universiti Sains Malaysia, Penang, Malaysia 
researchers (Jensen et al., 1972; Black, 1972; Fama and MacBeth, 1973) gave their supports to the standard form of CAPM. After 1980s, CAPM came under attack as the scientists (Reiganum, 1981; Elton et al., 1984; Bark, 1991) showed their strong evidence against the standard form of CAPM. In 2006, one study (Michailidis et al., 2006) in the Greek stock market provided evidence against the CAPM. Gursoy and Gulnara (2007) found no meaningful relationship between beta coefficients and risk premiums in Turkey stock market.

The stock markets play vital roles for the economy of any countries. There were lots of researches regarding the emerging stock markets (for example, for Taiwan stock market, Chiang et al. (2004); for Malaysian stock market, for Nigerian stock market, Agwuegbo et al. (2010); for Iranian stock exchange, Oskooe (2010) and for Indian stock market), but in Bangladesh, studies related to stock market were few. The objective of this study is to analyze and estimate the portfolio performance of Bangladesh stock market in the CAPM framework. This study is to investigate not only the validity of the CAPM in the portfolios but also the capital market behavior of Bangladesh over the period 2005-2009.

\subsection{Brief Description of Dhaka Stock Exchange (DSE)}

The Dhaka Stock Exchange (DSE) was first incorporated as the East Pakistan Stock Exchange Association Limited. It was renamed as Dhaka Stock Exchange (DSE) Limited on June 23, 1962. The service on the stock exchange continued successively until 1971. The trading was suspended during the liberation war and resumed in 1976 initially with 9 listed companies and total paid-up capital of $\mathrm{Tk}$. 137.52 million. At 31 October, 2010 the number of listed securities were 442 and the total issued capital of all listed securities was Tk. 646,490.00 million. The Securities and Exchange Commission (SEC) which is the regulator of the capital market of Bangladesh was established on 8th June, 1993. After the establishment of SEC, public interest to invest in the capital market has improved because of investment friendly rules and regulations. Foreign portfolio investment started to stream due to favorable regulatory conditions.

\subsection{Studies in DSE Market}

In DSE, there are several studies have been conducted for market efficiency. Hassan et al. (1999) studied on time-varying risk-return relationship for DSE market by utilizing a unique data set of daily stock prices and returns. He found that the DSE equity returns show positive skewness, excess kurtosis and deviation from normality and the returns display significant serial correlation, implying the stock market is inefficient. Haque et al. (2001) tested the Efficient Market Hypothesis (EMH) based on the data four months before and four months after the automation which was imposed in DSE market on 10th August, 1998. The test results indicated that the market does not improve and even after automation, manipulation continued. Kader and Rahman (2005) showed that there is no evidence that DSE is weak form efficient by using technical trading rule. Islam and Khaled (2005) analyzed on the predictability of the share price in Dhaka Stock Exchange prior to the boom in 1996 and found evidence in favor of short-term predictability of share prices in the Dhaka stock market prior to the 1996 boom. In order to test whether CAPM is a good indicator of asset pricing in Bangladesh, Rahman et al. (2006) considered Fama and French (1992) methodology on five variables (Stock market return, Beta, Book to market value, Market capitalization and Sales) and found that the variables have significant relationship with the stock return. Uddin and Alam (2007) examined the linear relationship between share price and interest rate, share price and growth of interest rate, growth of share price and interest rate and growth of share price and growth of interest rate which were determined by Ordinary Least-Square (OLS) regression. For all of the cases, they found that interest rate has significant negative relationship with share price and growth of interest rate has significant negative relationship with growth of share price in Dhaka Stock Market, which means that DSE is not weak form efficient. Alam et al. (2007) investigated the relationship between risk and the expected rate of return on a risky security by using the CAPM model and found that CAPM is invalid in DSE market. Uddin and Khoda (2009) investigated whether stock-price indexes of Dhaka stock market can be characterized as random walk (unit root) processes by using the Unit Root test and the ADF test. They provided evidence that the DSE is not efficient even in weak form and DSE does not follow the random walk model. Ali et al. (2010) tested the validity of the CAPM in the DSE market and concluded on weak practical implication of CAPM in this market. Mollik and Bepari (2011) tried to measure the risk and return relationship in DSE market and reported that there was statistically significant positive relationship between risk and return at the individual security level. This study is diferent from the previous studies because, here we find out the risk-return relationship among the portfolios of DSE market. 


\section{MATERIALS AND METHODS}

\subsection{Data Selection}

The data were collected from DSE market consisting 80 companies for the period of January 2005 to December 2009. This study selected 60 months as an estimation period because many studies (see for example Fama and French, 1996) use an estimation period of 60 months when employing monthly returns. DSE was concentrated in this research because it is the main and country's oldest stock exchange of Bangladesh.

Monthly data was used in this analysis, because the daily data, though better for estimating risk-return relationship, is very noisy (Basu and Chawla, 2010). The All Share Price Index (DSI) was used as a proxy for the market portfolio. This index is a market value weighted index which is comprised of all listed companies of the exchange and reflects general trends of the Bangladesh stock market. Furthermore, Bangladesh government 3-Month T-bill rate was used as the proxy for the risk-free asset.

\subsection{Portfolio Construction}

In order to test the validity of CAPM in portfolios, at first the construction of the portfolios is needed. For this construction, all the studied companies were arranged in descending order of beta and grouped into 10 portfolios of 8 stocks each such that Portfolio_1 contained the first 8 stocks representing the 8 highest beta values and Portfolio_10 contained the last 8 stocks representing the 8 lowest beta values. This was done to achieve diversification and reduce any errors that might occur due to the presence of residual variance (Amanulla and Kamaiah, 1997). This procedure generated 10 equally-weighted portfolios comprised of 8 companies in each in Table 3.

DSE prepares individual company's monthly closing price. Using the closing price of individual company, the return of individual company was calculated as follows: Individual Company's Return $=\operatorname{In}\left(\mathrm{P}_{\mathrm{t}}\right)$-In $\left(\mathrm{P}_{\mathrm{t}-1}\right)$ where, $\mathrm{P}_{\mathrm{t}}$ $=$ closing price at period $\mathrm{t} ; \mathrm{P}_{\mathrm{t}-1}=$ closing price at period $\mathrm{t}-$ 1 and $\ln =$ natural $\log$. In this study, portfolio's return was taken as a dependent variable. The portfolio's return can be found by using the individual company's return as follows (Michailidis et al., 2006):

$$
\mathrm{R}_{\mathrm{pl}}=\frac{\sum_{\mathrm{i}=1}^{\mathrm{k}} \mathrm{R}_{\mathrm{it}}}{\mathrm{k}}
$$

Where:

$\mathrm{k}=$ The number of companies included in each portfolio $(\mathrm{k}=8)$

$\mathrm{p}=$ The number of portfolios $(\mathrm{p}=1 \ldots 10)$

$\mathrm{R}_{\mathrm{it}}=$ The excess return on companies

\subsection{Estimation of the CAPM in Portfolios}

According to the CAPM and followed by Basu and Chawla (2010), returns can be explained as:

$\mathrm{R}_{\mathrm{pt}}=\mathrm{R}_{\mathrm{ft}}+\beta_{\mathrm{p}}\left(\mathrm{R}_{\mathrm{mt}}-\mathrm{R}_{\mathrm{ft}}\right)$

Where:

$\mathrm{R}_{\mathrm{pt}}=$ The return on portfolio $\mathrm{p}$ at time $\mathrm{t}$

$\mathrm{R}_{\mathrm{ft}}=$ The return on the risk free asset at time $\mathrm{t}$

$\mathrm{R}_{\mathrm{mt}}=$ The market return at time $\mathrm{t}$

$\mathrm{B}_{\mathrm{p}}=$ The beta of portfolio $\mathrm{p}$

The Equation (1) can be estimated using the two stages regression (Omran, 2007). In the first stage regression, time series data was used to estimate systematic risk and unique risk in the portfolios as follows:

$\mathrm{R}_{\mathrm{pt}}-\mathrm{R}_{\mathrm{ft}}=\alpha_{\mathrm{p}}+\beta_{\mathrm{p}}\left(\mathrm{R}_{\mathrm{mt}}-\mathrm{R}_{\mathrm{ft}}\right)+\mathrm{e}_{\mathrm{pt}}$

$\mathrm{UR}=\sigma_{\mathrm{p}}{ }^{2}-\beta_{\mathrm{p}}{ }^{2} \sigma_{\mathrm{m}}^{2}$

Where:

$\mathrm{e}_{\mathrm{pt}}=$ The random disturbance term in the regression equation at time $\mathrm{t}$

$\mathrm{UR}=$ Refers to the unique risk for the portfolio

$\sigma_{\mathrm{p}}{ }^{2}=$ Refers to the variance of the returns for the portfolio $\mathrm{p}$

$\sigma_{\mathrm{m}}{ }^{2}=$ Refers to the variance of the returns for index, the proxy for the market portfolio.

Equation 2 can be estimated using Ordinary Least Squares (OLS). Equation 3 measured Unique Risk (UR), which is the difference between the total variance of the returns on the portfolio and the portfolio's market risk.

The following second stage regression was a cross sectional regression Equation 4:

$\mathrm{R}_{\mathrm{pt}}-\mathrm{R}_{\mathrm{ft}}=\gamma_{0}+\gamma_{1} \beta_{\mathrm{pt}}+\gamma_{2} \beta_{\mathrm{pt}}{ }^{2}+\gamma_{3} \mathrm{UR}_{\mathrm{pt}}+\mathrm{e}_{\mathrm{pt}}$

Where:

$\mathrm{R}_{\mathrm{pt}}=$ The return on portfolio $\mathrm{p}$ at time $\mathrm{t}$

$\mathrm{R}_{\mathrm{ft}}=$ The return on the risk free asset at time $\mathrm{t}$

$\beta_{\mathrm{pt}}=$ The beta of portfolio $\mathrm{p}$ at time $\mathrm{t}$; representing systematic risk 
$\beta_{\mathrm{pt}}^{2}=$ The squared beta of portfolio $\mathrm{p}$ at time $\mathrm{t}$; representing non-linearity of returns

$\mathrm{UR}_{\mathrm{pt}}=$ The unique risk of portfolio $\mathrm{p}$ at time $\mathrm{t}$; representing unsystematic risk and

$\mathrm{e}_{\mathrm{pt}}=$ Random disturbance term in the regression equation at time $\mathrm{t} \gamma_{0}, \gamma_{1}, \gamma_{2}$ and $\gamma_{3}$ are the parameter to be estimated.

\subsection{Hypotheses of CAPM Testing}

For CAPM to hold true in the portfolios, the following hypothesises should be satisfied:

- $\gamma_{0}=0$, as any excess return earned should be zero for a zero-beta portfolio

- $\gamma_{1}>0$, as there should be a positive price for risk taken

- $\gamma_{2}=0$, as the Security Market Line (SML) should represent a linear relationship

- $\gamma_{3}=0$, as the unique risk which can be diversified away should not affect return

\section{RESULTS}

Table 1 contains summary statistics of the main variables as average return, beta and residual variance. The table shows that the average beta during the period was 0.2129 . The minimum beta was 0.0028 and the maximum beta was 0.5928 with a standard deviation of 0.1578 . However, there was no company that had a negative beta during the period. The mean average return for the period was $-2.94 \%$. The maximum return during the period was $-0.29 \%$ and the minimum return during the period was $-5.57 \%$, Table 2 contains the yearly average returns of the studied 80 companies. The maximum return yielding company was "Meghna Condensed Milk". Beta estimate for that company was 0.1191 . The minimum return yielding company was "National Tubes". Beta estimate for that company was 0.1772. From Fig. 1, it was found that return was increasing during the studied period except in the year between 2007 to 2008 .

Table 1. Summary statistics

\begin{tabular}{lrlr}
\hline & $\begin{array}{l}\text { Average } \\
\text { return }\end{array}$ & Beta & $\begin{array}{r}\text { Residual } \\
\text { variance }\end{array}$ \\
\hline Mean & -0.0294 & 0.2129 & 0.0252 \\
Standard deviation & 0.0114 & 0.1577 & 0.0189 \\
Minimum & -0.0557 & 0.0028 & 0.0039 \\
Median & -0.0301 & 0.1723 & 0.0218 \\
Maximum & -0.0029 & 0.5928 & 0.1578 \\
\hline
\end{tabular}

Table 2. Yearly average returns of the studied companies

\begin{tabular}{|c|c|c|c|c|c|}
\hline Companies average return & 2005 & 2006 & 2007 & 2008 & 2009 \\
\hline Aftab Automobiles & -0.1055 & -0.0669 & -0.0386 & -0.0363 & 0.0967 \\
\hline Aziz pipes & -0.0775 & -0.0370 & 0.0690 & -0.0664 & 0.0305 \\
\hline Olympic industries & -0.1027 & -0.0435 & 0.0027 & -0.0137 & 0.0664 \\
\hline Bangladesh lamps & -0.0755 & -0.0692 & -0.0135 & -0.0186 & -0.0065 \\
\hline Eastern cables & -0.0674 & -0.0405 & 0.0297 & -0.0548 & -0.0345 \\
\hline Monno Jutex & -0.0675 & -0.0654 & -0.0270 & -0.0341 & 0.0424 \\
\hline Monno Stafllers & -0.0560 & -0.0382 & -0.0591 & -0.0282 & 0.0061 \\
\hline Singer bangladesh & -0.0908 & -0.0719 & 0.0248 & -0.0465 & -0.0214 \\
\hline Atlas Bangladesh & -0.0796 & -0.0694 & 0.0032 & -0.0658 & -0.0270 \\
\hline BD.Autocars & -0.0768 & -0.0135 & 0.0217 & -0.0454 & 0.0414 \\
\hline Quasem drycells & -0.1023 & -0.0621 & 0.0094 & 0.0160 & -0.0176 \\
\hline Renwick Jajneswar & -0.0683 & -0.0539 & 0.0080 & 0.0579 & -0.0156 \\
\hline National tubes & -0.0817 & -0.0813 & -0.0027 & -0.0600 & -0.0528 \\
\hline Anwar Galvanizing & -0.0994 & -0.0430 & -0.0203 & -0.0263 & 0.0364 \\
\hline Kay and Que & -0.1030 & -0.0608 & -0.0036 & 0.0099 & -0.0235 \\
\hline Rangpur Foundry & -0.0686 & -0.0604 & -0.0074 & 0.0220 & -0.0095 \\
\hline National Polymer & -0.0212 & -0.0287 & -0.0251 & -0.0311 & -0.0247 \\
\hline Alpha Tobac & -0.1356 & -0.0490 & -0.0541 & -0.0391 & 0.0182 \\
\hline Apex foods & -0.1094 & -0.0447 & 0.0050 & -0.0324 & -0.0258 \\
\hline Bangas & -0.0845 & -0.0602 & -0.0192 & -0.0269 & 0.1021 \\
\hline BATB & -0.0834 & -0.0588 & -0.0026 & -0.0246 & 0.0090 \\
\hline National tea & -0.0875 & -0.0651 & -0.0152 & 0.0141 & 0.0098 \\
\hline o synthetics & -0.1180 & -0.0345 & -0.0307 & -0.0058 & 0.0182 \\
\hline Zeal B & -0.0691 & 0.0648 & -0.0422 & -0.0140 & -0.0442 \\
\hline Ban & .0422 & -0.0339 & -0.0423 & -0.0008 & -0.0386 \\
\hline $\mathrm{AMCL}$ & -0.0824 & -0.0582 & -0.0109 & -0.0035 & -0.0155 \\
\hline ugar & .0675 & 0.0317 & -0.0314 & -0.0226 & -0.0205 \\
\hline Rahi & -0.0560 & 0.0441 & -0.0541 & -0.0284 & 0.0482 \\
\hline Megh & .0926 & 0.0317 & -0.0706 & -0.0068 & 0.0699 \\
\hline nsed. & .0593 & 0.0330 & -0.0251 & -0.0180 & 0.0550 \\
\hline y Ltd. & -0.0900 & -0.0590 & -0.0477 & -0.0103 & 0.1358 \\
\hline $\mathrm{BOC}$ & -0.0734 & -0.0428 & 0.0326 & -0.0657 & 0.0004 \\
\hline $\mathrm{Pad}$ & .0088 & -0.0507 & 0.0206 & -0.0480 & -0.1200 \\
\hline Elec. & .0631 & -0.0156 & 0.0303 & -0.0309 & 0.0333 \\
\hline & -0.0543 & -0.0812 & -0.0557 & -0.0088 & 0.0239 \\
\hline & .0615 & -0.0586 & -0.0027 & -0.0369 & 0.0331 \\
\hline Desh & -0.0573 & -0.0452 & -0.0415 & -0.0533 & 0.0731 \\
\hline Duls & .0545 & -0.0482 & -0.0963 & -0.0102 & 0.0440 \\
\hline & .0294 & -0.0819 & -0.0572 & -0.0 & 0.0257 \\
\hline Bex & & -0.0 & -0.0642 & -0.0304 & 0.0521 \\
\hline & .0760 & -0.0732 & -0.0051 & -0.0132 & -0.0046 \\
\hline & & & -0.0318 & -0.0163 & 0.0633 \\
\hline Textiles & .0396 & -0.0669 & -0.0377 & 0.0101 & 0.0126 \\
\hline & .0673 & & -0.0137 & -0.0231 & 0.0425 \\
\hline Ltd. & .0743 & -0.0460 & -0.0416 & -0.0510 & 0.0026 \\
\hline & .0698 & & -0.0315 & -0.0196 & 0.0238 \\
\hline & .0936 & -0.0 & -0.0057 & -0.0569 & -0.0543 \\
\hline Metı & .0577 & -0.0671 & -0.0242 & 0.0362 & -0.0204 \\
\hline & .0730 & -0.0584 & -0.0353 & 0.0232 & -0.0098 \\
\hline & 88 & -0.0561 & -0.0423 & 0.0372 & -0.0561 \\
\hline & & & -0.0205 & -0.0053 & 0.0156 \\
\hline & .0754 & -0.0 & 0.0293 & 0.0378 & -0.0628 \\
\hline & & & 0.02 & -0.0 & -0.0136 \\
\hline ckiser & 66 & -0.0 & 0.0098 & -0.03 & 0.0547 \\
\hline & 56 & & -0.0669 & -0.0 & -0.0249 \\
\hline & & -0.0 & 0.04 & -0.0326 & -0.0344 \\
\hline The Ib & -0.0738 & -0.0635 & -0.0117 & -0.0304 & -0.0130 \\
\hline Libra I & .0724 & -0.0580 & -0.0221 & -0.0095 & 0.0016 \\
\hline & & -0.05 & -0.0781 & -0.0014 & 0.0685 \\
\hline & & & & & -0.0576 \\
\hline & .0783 & -0.0512 & -0.0486 & -0.0296 & 0.0570 \\
\hline & & & & & -0.0023 \\
\hline & & & 0.0 & -0.0 & 0.0733 \\
\hline & .0788 & -0.0402 & -0.0299 & -0.0424 & 0.0514 \\
\hline & .0931 & -0.0052 & 0.0103 & -0.0851 & 0.0000 \\
\hline & .0905 & 0.0004 & 0.0101 & -0.0364 & 0.0465 \\
\hline & & & -0.0526 & & 0.0944 \\
\hline & .0537 & -0.0551 & -0.0329 & -0.0446 & -0.0513 \\
\hline & & & & & -0.0121 \\
\hline & .0764 & -0.0775 & -0.0190 & -0.0028 & 0.0043 \\
\hline & 0.0475 & & -0.02 & $-0.02-2$ & -0.0 \\
\hline Agni Systems Ltd. & & & & -0.0066 & -0.0 \\
\hline Apex tannery & .0921 & -0.0378 & 0.0142 & 0.0019 & -0.0267 \\
\hline & & & 0.0009 & & \\
\hline & & & 0.0784 & & \\
\hline & & & 0.01 & -0.0174 & -0.0 \\
\hline & & & -0.0 & 0.0411 & -0.0024 \\
\hline Mo & 8 & & -0.0 & -0.0458 & 0.0 \\
\hline & & & & & \\
\hline Beximco & -0.0677 & -0.0660 & -0.0457 & 0.0834 & -0.0074 \\
\hline & -0.0741 & -0.0444 & -0.0154 & -0.0213 & 0.0081 \\
\hline
\end{tabular}




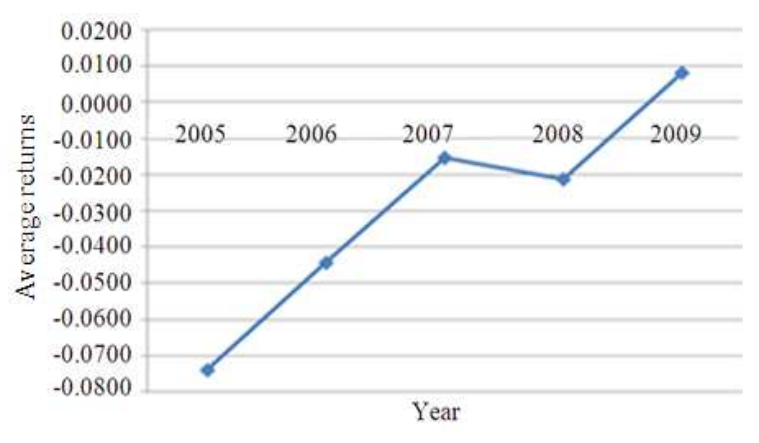

Fig. 1. Yearly average returns of the companies

\section{DISCUSSION}

\subsection{Significance of Stock Beta Coefficient Estimates}

From Table 3, it was found that the beta coefficients for 25 individual stocks were statistically significant at $1 \%$ level of significance, 6 individual stocks were statistically significant at 5\% level of significance and 3 individual stocks were statistically significant at $10 \%$ level of significance. The remaining 46 companies were statistically insignificant. Among the 80 companies, the highest beta attainable company was "Square Textile" $(\beta$ $=0.5928)$ and the lowest beta attainable company was "Monno Stafllers" ( $\beta=0.0028)$.

\subsection{Estimates of the OLS Regression of the Constructed Portfolios}

According to the critical condition of CAPM, the intercept term, the coefficient of beta-squared and the unique risk should not be significantly different from zero and the coefficient of beta should be positive and significant. Therefore, for intercept, beta-squared and residual variance terms a two-tailed test was used whereas for slope term a one-tailed test was used. The results of Table 4 indicated that for all the 10 portfolios, the intercept terms were not significantly different from zero. Also, among the 10 portfolios, the coefficients of squared beta and unique risk were insignificant. These outcomes indicated that the "expected return-beta" relationship was linear in portfolios and unique risk had no affect on the expected return of the 10 portfolios. These conclusions were partially contradicted to the findings of Omran (2007) in terms of intercept and unique risk and fully contradicted to the findings of Basu and Chawla (2010) in terms of intercept, squared beta and unique risk. In order to test the CAPM, Omran (2007) examined 42 individual companies in the Egyptian stock market and found that the intercept term is significantly different from zero at 5\% level of significance and the unique risk has no affect on the expected return of the individual company. In the other study, Basu and Chawla (2010) showed that the intercept terms are significantly different from zero for all the 10 portfolios, the coefficients of beta-squared are significant in five portfolios and the coefficients of unique risk are significant in four portfolios out of 10 portfolios in the Indian stock market.

In this study, the coefficients of beta were found to be negative in three portfolios (Portfolio 2, 7 and 9) out of 10 portfolios and for all portfolios the coefficients of beta were statistically insignificant. The outcomes in terms of beta coefficients were almost similar to the findings of Claessens and Glen (1995) and Basu and Chawla (2010) and fully dissimilar to the findings of Omran (2007). Claessens and Glen (1995) showed in his research that beta coefficients are negative and insignificant in the 11 country's stock market (for example, Chile, India, Indonesia, Portugal, Thailand, Venezuela and Zimbabwe) out of 20 country's stock market. Basu and Chawla (2010) found that the beta coefficients are insignificant in 7 portfolios out of 10 portfolios whereas Omran (2007) showed that the coefficients of beta are statistically significant at 5\% level of significance. Hence, based on the slope criterion the CAPM hypothesis cannot be accepted for the portfolios in the context of DSE market which was supportive to the findings of Michailidis et al. (2006) in the Greek stock market and Sehgal (1997) and Manjunatha and Mallikarjunappa (2006) in the Indian stock market. So, CAPM is not a good indicator of asset pricing in Bangladesh stock market which is contradicted to the studies of developed country's stock market (Sauer and Murphy, 1992; Limmack and Ward, 1990) and developing country's stock market (Srinivasan, 1988; Dhankar and Kumar, 2007).

\subsection{Comparison between Average Portfolio Returns and Portfolio Betas}

From Table 5, it was noticed that that the range of the estimated stock portfolio betas was between -1.012 the minimum and 3.999 the maximum. Among the 10 portfolios, the highest beta attainable portfolio was "Portfolio 3" $(\beta=3.991)$ and the lowest beta attainable portfolio was "Portfolio 2 " $(\beta=-1.012)$. The results of the portfolio did not support that "higher risk (beta) is associated with a higher level of return". For example, Portfolio 3, the highest beta portfolio produced lower return (Return $=-0.0315$ ) than the Portfolio 2, the lowest beta portfolio (Return $=-0.0309$ ). The highest return (Return $=-0.0249)$ yielding portfolio was Portfolio 6 whereas the lowest return (Return $=-0.0379$ ) yielding portfolio was Portfolio 1. 
Table 3. Results of the stock beta coefficient estimates and constructs the final 10 Portfolios

\begin{tabular}{|c|c|c|c|c|c|c|c|}
\hline Portfolio & Company & Beta & t- value & Portfolio & Company & Beta & t-value \\
\hline \multirow[t]{8}{*}{1} & Square textile & $0.5928^{*}$ & 5.60 & \multirow[t]{8}{*}{6} & Rahima Food & $0.1694^{(a)}$ & 1.31 \\
\hline & Heidelberg cement & $0.5592^{*}$ & 5.13 & & Anwar Galvanizing & $0.1639^{@}$ & \\
\hline & Lafarge surma cement & $0.5507^{*}$ & 5.02 & & Bangas & $0.1625^{@}$ & 1.25 \\
\hline & Singer bangladesh & $0.5486^{*}$ & 4.90 & & BDCOM Online Ltd. & $0.1624^{@}$ & 1.25 \\
\hline & Bangladesh lamps & $0.5176^{*}$ & 4.60 & & Renwick Jajneswar & $0.1520^{@}$ & 1.17 \\
\hline & BOC bangladesh & $0.4938^{*}$ & 4.32 & & $\begin{array}{l}\text { Pharma Aids } \\
\text { Pids }\end{array}$ & $0.1512^{@}$ & 1.16 \\
\hline & Confidence cement & $0.4599^{*}$ & 3.94 & & Atlas Bangladesh & $0.1442^{@}$ & 1.11 \\
\hline & Apex foods & $0.4452^{*}$ & 3.78 & & Rangpur Foundry & $0.1440 @$ & 1.10 \\
\hline \multirow[t]{8}{*}{2} & Apex adelchy Ft. & $0.4174^{*}$ & 3.49 & \multirow[t]{8}{*}{7} & Saiham Textile & $0.1427^{@}$ & 1.09 \\
\hline & Eastern cables & $0.4123^{*}$ & 3.40 & & Libra Infusions Limited & $0.1419^{@}$ & 1.09 \\
\hline & Beximco pharma & $0.3959^{*}$ & 3.28 & & Meghna Condensed. & $0.1191^{@}$ & 0.91 \\
\hline & Niloy cement & $0.3913^{*}$ & 3.23 & & Kay and Que & $0.1104^{@}$ & 0.85 \\
\hline & Reckitt benckiser & $0.3891^{*}$ & 3.21 & & Agni Systems Ltd. & $0.1091^{@}$ & 0.84 \\
\hline & BATBC & $0.3780^{*}$ & 3.10 & & Dulamia Cotton & $0.1040 @$ & 0.80 \\
\hline & The Ibn sina & $0.3761^{*}$ & 3.09 & & Legacy Footwear & $0.0972^{@}$ & 0.74 \\
\hline & Meghna cement & $0.3660^{*}$ & 2.99 & & Fu-Wang Ceramic & $0.0968^{@}$ & 0.74 \\
\hline \multirow[t]{8}{*}{3} & Bextex limited & $0.3632^{*}$ & 2.97 & \multirow[t]{8}{*}{8} & Sonargaon Textiles & $0.0914^{@}$ & 0.70 \\
\hline & Olympic industries & $0.3514^{*}$ & 2.85 & & Stylecraft & $0.0898^{@}$ & 0.69 \\
\hline & Renata Ltd. & $0.3479^{*}$ & 2.82 & & Padma Cement & $0.0754^{@}$ & 0.58 \\
\hline & Apex tannery & $0.3470^{*}$ & 2.81 & & Beach Hatchery Ltd. & $0.0736^{@}$ & 0.56 \\
\hline & Bata shoe & $0.3382^{*}$ & 2.73 & & Aftab Automobiles & $0.0726^{@}$ & 0.55 \\
\hline & ACI limited. & $0.3330^{*}$ & 2.69 & & National Polymer & $0.0717^{@}$ & 0.55 \\
\hline & AMCL (Pran) & $0.3306^{*}$ & 2.66 & & Orion Infusion & $0.0679 @$ & 0.52 \\
\hline & Square pharma & $0.3229^{*}$ & 2.59 & & Monno Jutex & $0.0661 @$ & 0.50 \\
\hline \multirow[t]{8}{*}{4} & Aramit Cement & $0.2959^{*}$ & 2.36 & \multirow[t]{8}{*}{9} & BD.Autocars & $0.0660^{@}$ & 0.50 \\
\hline & Padma oil co. & $0.2761^{* *}$ & 2.19 & & Alltex Ind. Ltd. & $0.0655^{@}$ & 0.50 \\
\hline & Beximco & $0.2732^{* *}$ & 2.16 & & Samata Leather & $0.0651^{@}$ & 0.49 \\
\hline & Quasem drycells & $0.2691^{* *}$ & 2.12 & & Bd.Welding Elec. & $0.0634^{@}$ & 0.48 \\
\hline & Aziz pipes & $0.2641^{* *}$ & 2.09 & & Shaympur Sugar & $0.0501 @$ & 0.38 \\
\hline & Delta spinners & $0.2635^{* *}$ & 2.08 & & Metro Spinning & $0.0479^{@}$ & 0.37 \\
\hline & Information services & $0.2503^{* *}$ & 1.97 & & Desh Garmants & $0.0349 @$ & 0.27 \\
\hline & Glaxo smithkline & $0.2433^{* * *}$ & 1.91 & & Tallu Spinning & $0.0321 @$ & 0.24 \\
\hline \multirow[t]{8}{*}{5} & Apex spinning. & $0.2202^{* * *}$ & 1.72 & \multirow[t]{8}{*}{10} & Alpha Tobacco & $0.0299 @$ & 0.23 \\
\hline & Therapeutics & $0.2116^{* * *}$ & 1.65 & & Zeal Bangla Sugar & $0.0283^{@}$ & \\
\hline & Beximco synthetics & $0.1943^{@}$ & 1.51 & & Monno Ceramic & $0.0192^{@}$ & 0.15 \\
\hline & $\begin{array}{l}\text { Prime textile } \\
\end{array}$ & $0.1926^{@}$ & 1.49 & & Bangladesh Plan. & $0.0175^{@}$ & 0.13 \\
\hline & National tea & $0.1820^{@}$ & 1.40 & & In Tech Online Ltd. & $0.0166^{@}$ & 0.13 \\
\hline & H.R.textile & $0.1773^{@}$ & 1.37 & & Samorita Hospital & $0.0123^{@}$ & 0.09 \\
\hline & National tubes & $0.1772^{@}$ & 1.37 & & Meghna Pet Ind. & $0.0091^{@}$ & 0.06 \\
\hline & Ambee pharma & $0.1753^{@}$ & 1.36 & & Monno Stafllers & $0.0028^{@}$ & 0.02 \\
\hline
\end{tabular}

*,**,***: Significance level at 1, 5, 10\% consecutively, @ means insignificant, S.E = Standard Error

Table 4. Results of the OLS regression in 10 portfolios

\begin{tabular}{|c|c|c|c|c|c|}
\hline $\begin{array}{l}\text { Portfolio } \\
\text { no }\end{array}$ & $\begin{array}{l}\text { Coefficient/ } \\
\text { t-value }\end{array}$ & Constant & $\beta$ & $\beta^{2}$ & $\begin{array}{l}\text { Residual } \\
\text { variance }\end{array}$ \\
\hline \multirow[t]{2}{*}{1} & Coefficient & $-0.747^{@}$ & $1.147^{@}$ & $-1.188^{(a)}$ & $0.035^{@}$ \\
\hline & t-value & -0.783 & 0.804 & -0.857 & 0.338 \\
\hline \multirow[t]{2}{*}{2} & Coefficient & $1.648^{@}$ & $-1.012^{@}$ & $1.039^{@}$ & $-0.038^{@}$ \\
\hline & $\mathrm{t}$-value & 0.373 & -0.384 & 0.390 & -0.416 \\
\hline \multirow[t]{2}{*}{3} & Coefficient & $-7.825^{@}$ & $3.999^{@}$ & $-3.971^{@}$ & $0.007^{@}$ \\
\hline & $\mathrm{t}$-value & -0.825 & 0.812 & -0.800 & 0.071 \\
\hline \multirow[t]{2}{*}{4} & Coefficient & $-0.431^{@}$ & $0.256^{@}$ & $-0.247^{@}$ & -0.014@ \\
\hline & t-value & -0.192 & 0.179 & -0.173 & -0.273 \\
\hline \multirow[t]{2}{*}{5} & Coefficient & $-0.729^{@}$ & $0.719^{@}$ & $-0.703^{@}$ & $-0.070^{@}$ \\
\hline & t-value & -0.431 & 0.418 & -0.410 & -1.213 \\
\hline \multirow[t]{2}{*}{6} & Coefficient & $-4.131^{@}$ & $2.857^{@}$ & $-2.858^{@}$ & $0.005^{@}$ \\
\hline & t-value & -0.960 & 0.955 & -0.957 & 0.080 \\
\hline \multirow[t]{2}{*}{7} & Coefficient & $0.455^{@}$ & $-0.839^{@}$ & $0.853^{@}$ & $0.039^{@}$ \\
\hline & t-value & 0.539 & -0.574 & 0.576 & 0.502 \\
\hline \multirow[t]{2}{*}{8} & Coefficient & $-0.176^{@}$ & $0.208^{@}$ & $-0.204^{@}$ & $0.008^{@}$ \\
\hline & t-value & -0.190 & 0.156 & -0.150 & 0.095 \\
\hline \multirow[t]{2}{*}{9} & Coefficient & $-0.006^{@}$ & $-0.079^{@}$ & $0.057^{@}$ & $0.041^{@}$ \\
\hline & t-value & -0.029 & -0.126 & 0.091 & 0.701 \\
\hline \multirow[t]{2}{*}{10} & Coefficient & $-0.035^{@}$ & $0.059^{@}$ & $-0.091^{@}$ & $-0.003^{@}$ \\
\hline & t-value & -0.684 & 0.204 & -0.280 & -0.036 \\
\hline
\end{tabular}

*,**,*** Significance level at 1, 5,10\% consecutively, @ means insignificant, S.E = Standard Error 
Table 5. Comparison between average portfolio returns and portfolio betas

\begin{tabular}{llc}
\hline Portfolio No. & Average portfolio return & Portfolio beta \\
\hline Portfolio_1 & -0.0379 & 1.147 \\
Portfolio_10 & -0.0313 & 0.059 \\
Portfolio_2 & -0.0309 & -1.012 \\
Portfolio_3 & -0.0315 & 3.999 \\
Portfolio_4 & -0.0279 & 0.256 \\
Portfolio_5 & -0.0323 & 0.719 \\
Portfolio_6 & -0.0249 & 2.857 \\
Portfolio_7 & -0.0274 & -0.839 \\
Portfolio_8 & -0.0254 & 0.208 \\
Portfolio_9 & -0.0280 & -0.079 \\
\hline
\end{tabular}

The CAPM theory indicates that higher risk (beta) is associated with a higher level of return. The results of the study did not support this hypothesis. Hasan et al. (2012) was also found the same results in the context of of individual companies in DSE market.

\section{CONCLUSION}

The article analyzes the portfolio performance and examines the validity of CAPM in the portfolios for the Dhaka Stock Exchange market. The results of the coefficients of squared beta and unique risk indicate that the "expected return-beta" relationship is linear in portfolios and unique risk has no affect on the expected return of the 10 portfolios. The intercept terms for the 10 portfolios are not significantly different from zero. The above three findings support the validity of CAPM. But, the CAPM's prediction for the slope is "slope should be positive and significant". The results in term of slope of this research contradict the above hypothesis and indicate evidence against the CAPM in the portfolios. This study concludes the practical incompleteness of CAPM and can motivate researcher to search further for a sound pricing mechanism in future.

\section{REFERENCES}

Agwuegbo, S.O.N., A.P. Adewole and A.N. Maduegbuna, 2010. A random walk model for stock market prices. J. Math. Stat., 6: 342-346. DOI: 10.3844/jmssp.2010.342.346

Alam, M.M., K.A. Alam and M.G.S. Uddin, 2007. Market depth and risk return analysis of dhaka stock exchange: An empirical test of market efficiency. ASA Univ. Rev., 1: 93-101.

Ali, M.H., S. Islam and M.M. Chowdhury, 2010. Test of CAPM in emerging stock markets: A study on Dhaka stock exchange. The Cost and Management.
Amanulla, S. and B. Kamaiah, 1997. Asset price behaviour in Indian stock market: Is conditional CAPM relevant? J. Finan. Manage. Anal., 39: 421-456.

Bark, H.K.K., 1991. Risk, return and equilibrium in the emerging markets: Evidence from the Korean stock market. J. Econ. Bus., 43: 353-362. DOI: 10.1016/0148-6195(91)90031-Q

Basu, D. and D. Chawla, 2010. An empirical test of CAPM-the case of indian stock market. Global Bus. Rev., 11: 209-220. DOI: 10.1177/097215091001100206

Black, F., 1972. Capital market equilibrium with restricted borrowing. J. Bus., 48: 444-445.

Chiang, M., R. Lai and H. Lee, 2004. The mechanism of stock market integration: Evidence for the Taiwan and U.S. Stock markets. Am. J. Applied Sci., 1: 1-4. DOI: 10.3844/ajassp.2004.1.4

Claessens, S. and J.D. Glen, 1995. The Cross-Section of Stock Returns: Evidence from the Emerging Markets. 1st Edn., World Bank Publications, pp: 18.

Dhankar, R.S. and R. Kumar, 2007. Relevance of CAPM to Indian stock market. The ICFAI J. Applied Finan., 13: 76-89.

Elton, E.J., J.G. Martin and J. Rentzler, 1984. The exdividend day behavior of stock prices: A reexamination of the clientele effect: Comment. J. Finance, 39: 551-556.

Fama, E. F. and K.R. French, 1992. The cross-section of expected stock returns. J. Finance, 47: 427-465.

Fama, E.F. and J.D. MacBeth, 1973. Risk, return and equilibrium: Empirical tests. J. Polit. Economy, 81: 607-636.

Fama, E.F. and K.R. French, 1996. Multifactor explanations of asset pricing anomalies. J. Finance, 51: 55-84. DOI: $10.1111 /$ j.15406261.1996.tb05202.x

Gursoy, C.T. and R. Gulnara, 2007. Test of capital asset pricing model in turkey. Dogus Univ. J., 8: 47-58.

Haque, M., R. Shamsul and M.E. Ahmed, 2001. Risk return and market efficiency in capital market under distress: Theory and evidence from DSE.

Hasan, M.Z., A.A. Kamil, A. Mustafa and M.A. Baten, 2012. Relationship between risk and expected returns: Evidence from the dhaka stock exchange. Proc. Econ. Finance, 2: 1-8. DOI: 10.1016/S22125671(12)00058-5

Hassan, M., M.A. Kabir, Islam and S.A. Basher, 1999. Market efficiency, time-varying volatility and equity returns in bangladesh stock market. Department of Economics, York University. 
Islam, A. and M. Khaled, 2005. Tests of weak-form efficiency of the dhaka stock exchange. J. Bus. Finan. Acc., 32: 1613-1624. DOI: 10.1111/j.0306686X.2005.00642.X

Jensen M.C., F. Black and M.S. Scholes, 1972. The capital asset pricing model: Some empirical tests. Social Science Electronic Publishing (SSEP), Inc.

Kader, A.A. and A.F.M.A. Rahman, 2005. Testing the weak-form efficiency of an emerging market: Evidence from the Dhaka stock exchange of Bangladesh. AIUB J.

Limmack, R.J. and C.W.R. Ward, 1990. The october 1987 stock market crash: An exploratory analysis of share price models. J. Bank. Finan., 14: 273-289. DOI: 10.1016/0378-4266(90)90050-C

Lintner, J., 1965. Security prices, risk and maximal gains from diversification. J. Bus., 20: 587-615. DOI: 10.1111/j.1540-6261.1965.tb02930.x

Manjunatha, T. and T. Mallikarjunappa, 2006. An Empirical testing of risk factors in the returns on Indian capital market. Decision, 33: 93-110.

Markowitz, H.M., 1952. Portfolio selection. J. Finan., 7: 77-91.

Michailidis, G., T. Stavros, P. Demetrios and M. Eleni, 2006. Testing the Capital Asset Pricing Model (CAPM): The case of the emerging greek securities market. Int. Res. J. Finance Econ., 4: 78-91. DOI: 2159/11466

Mollik, A.T. and M.K. Bepari, 2011. Risk-return tradeoff in dhaka stock exchange, Bangladesh: An emerging market evidence.

Mossin, J., 1968. Optimal multiperiod portfolio policies. J. Bus., 4: 215-229.

Omran, M.F., 2007. An analysis of the capital asset pricing model in the egyptian stock market. Q. Rev. Econ. Finan., 46: 801-812.
Oskooe, S.A.P., 2010. Emerging stock market performance and economic growth. Am. J. Applied Sci., 7: 265-269. DOI: 10.3844/ajassp.2010.265.269

Rahman, M., M.A. Baten and A. Alam, 2006. An empirical testing of capital asset pricing model in Bangladesh. J. Applied Sci., 6: 662-667. DOI: $10.3923 /$ jas.2006.662.667

Reiganum, M.R., 1981. Misspecification of capital asset pricing. J. Finance Econ., 9: 19-46. DOI: 10.1016/0304- 05X(81)90019-2

Sauer, A. and A. Murphy, 1992. An empirical comparison of alternative models of capital asset pricing in Germany. J. Bank. Finan., 16: 183-196.

Sehgal, S., 1997. An empirical testing of three parameter capital asset pricing model in India. Finan. India, 11: 919-940.

Sharpe, W.F., 1964. Capital asset prices: A theory of market equilibrium under conditions of risk. J. Finance, 19: 425-442. DOI: 10.1111/j.15406261.1964.tb02865.x

Srinivasan, S., 1988. Testing of capital assets pricing model in Indian environment.

Tobin, J., 1958. Liquidity preference as behavior towards risk. Rev. Econ. Stud., 25: 65-86.

Uddin, M.G.S. and M.M. Alam, 2007. The impacts of interest rate on stock market: Empirical evidence from dhakastock exchange. South Asian J. Manage. Res., 1: 123-132.

Uddin, M.G.S. and N. Khoda, 2009. Testing random walk hypothesis for Dhaka stock exchange: An empirical examination. Int. Res. J. Finan. Econ., 33: 64-76. 